Este ensaio tem como objetivo ilustrar a abordagem metodológica e os resultados alcançados com o último restauro, visando a busca de uma nova e atualizada restituição estética do ciclo pictórico. O objetivo principal foi recuperar a unidade potencial do texto pictórico, fragmentada pelas inúmeras lacunas expostas por restauros anteriores, respeitando as características materiais das pinturas e, de maneira compatível com as instâncias expressas pela propriedade, preservando os traços de sua história conservadora particular.

O grupo de trabalho interdisciplinar reconstruiu a complexa história conservadora das pinturas de parede removidas, graças à observação técnica da superfície e à caracterização científica dos materiais constituintes. Os resultados foram comparados com a documentação histórica disponível, em particular com as fotografias da época. O projeto permitiu-nos rever as profundas mudanças que o conceito de reintegração pictórica encontrou ao longo do tempo, desde o início do século XX até aos dias atuais. A intervenção também nasceu da necessidade da Pinacoteca di Brera atualizar a apresentação estética dos trabalhos, facilitando assim a leitura das imagens incompletas dos trabalhos devido às inúmeras lacunas.

Palavras-chave: histórico de conservação, reintegração, lagoa, pintura mural, Donato Bramante

\section{Conservation history of the paintings}

The treatment on the famous cycle of detached wall paintings depicting Men at arms and Heraclitus and Democritus by Donato Bramante was entrusted in 2016 by the Pinacoteca di Brera to the Conservation and Restoration Center "La Venaria Reale" (hereinafter CCR) during the reorganization of the Milanese museum, concluded in 2018.

The cycle, now on display in the section dedicated to the Lombard Art of the XV-XVI century, is composed of seven paintings depicting men in armor of classical inspiration, partly fragmentary (only in two of the detached frescoes a complete figure is preserved).

The paintings, dated to $1487-88$ during Bramante's stay in Lombardy, were frescoed in a room on the first floor of the house of the Milanese aristocratic poet Gaspare Ambrogio Visconti. To these, we add a painting featuring the philosophers Heraclitus and Democritus, once located in a nearby room and transferred in the eighteenth century in the same room where Men at Arms were placed (VV. AA. 2015).

Purchased by Pinacoteca di Brera in 1901 upon the will of Corrado Ricci, the eight paintings were detached, with many complications, by conservators Francesco and Giuseppe Annoni, under the supervision of Luca Beltrami, Luigi Cavenaghi and Gaetano Moretti (VV. AA. 1988).

In 1901, all eight frescoes were symmetrically inserted in the neoclassical architectural decoration of the room, realized in the second half of the 18th century, which covered most of the figures leaving only the bust of the images originally painted in full view (VV. AA. 2015).

The figures showed evident remakes, as proved by the photographic documentation available before the treatment of 1901, with particular reference to the Man with a Two-Handed Sword (the only figure still fully visible in the early twentieth century) and to the architectural backgrounds of the other half-length figures (Historical Archive of Pinacoteca di Brera) [Figure 1].

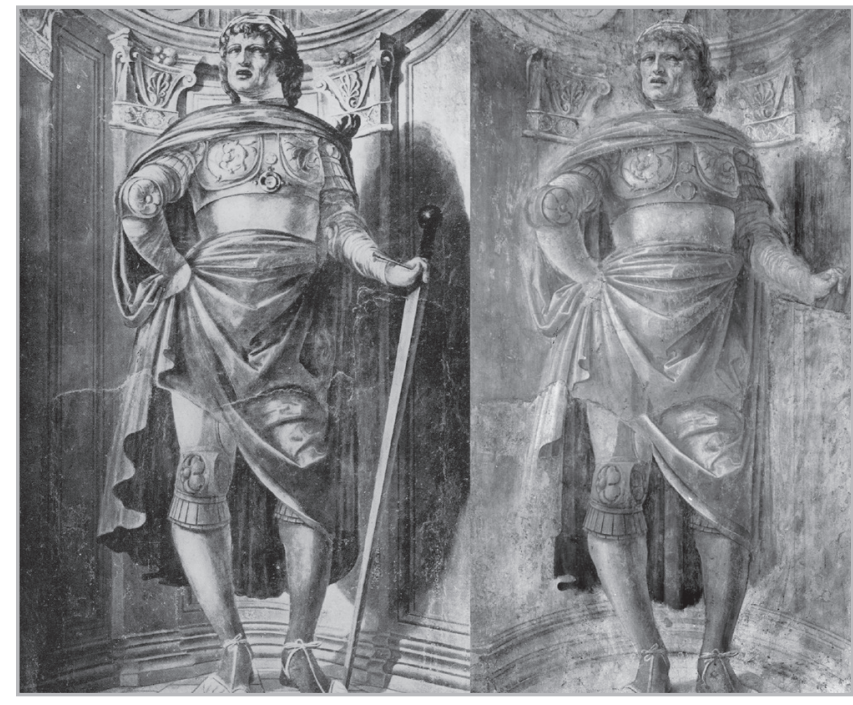

Figure 1.- Man with a Two-Handed Sword: historical photographs before and after the 1901 treatment

One of the main merits of the 1901 treatment is precisely that of having removed the eighteenth-century remakes, recovering in most cases the original painting. While placing itself in the Lombard tradition of restoration (not to mention in this context the Lombard supremacy in the detaching of frescoes from Giovanni Secco Suardo to the Steffanoni, following Giannini 2006 and 2013), from the historical photographs emerges a rather respectful aesthetic restitution of the original parts by Bramante, aimed at rebalancing the fragments as a whole and not altering their nature as wall paintings (Autelli 1989).

In 1976, thanks to a series of studies and the conservation treatment carried out by Mrs. Pinin Brambilla, the artworks were exhibited in Brera in a room that offered once more the reconstruction of their original location (Mulazzani et al. 1977). During this conservation treatment, in-depth analyses were carried out to study the technique, the materials and the state of conservation of the pictorial surface. Mrs. Brambilla, examining the artworks before the restoration, revealed the traces of at least 3 conservation treatment from 1901 onwards, recognizable by the different way of treating the lacunae [Figure 2]. 


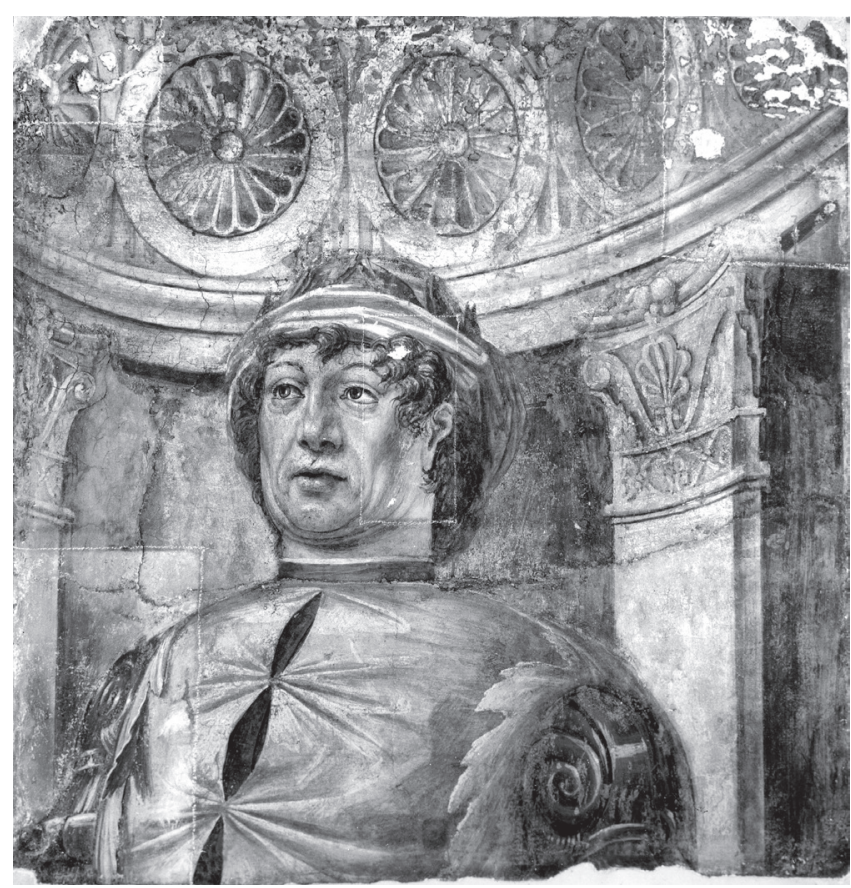

Figure 2.- Poet laureate with red hat: historical photograph during Mrs. Brambilla's conservation treatment (1976).

After entering in Brera, other conservation treatment before 1976 are not documented but it is likely that more localized interventions have been conducted, mainly with an aesthetic purpose.

In the case of the 1976 treatment, the delicate problem of the lacunae was tackled differently and in most cases resorted to neutral retouching, according to a criterion of archaeological taste widely used in the 1970s and supported by the methodological reflections by Paul Philippot until the debate born from the proposals of Umberto Baldini (Casazza 2007; Basile 2014).

In particular, the abrasions were treated with lightly tuned watercolor glazes; the small lacunae in correspondence of backgrounds, where the reconstruction of figurative elements was not foreseen, were leveled and underwent mimetic integration, also with watercolors. The lacunae in decorations or figurative elements that can be easily reconstructed, without problems of interpretation, have been infilled at the level of the original pictorial film and integrated with the recognizable technique of the "broken line" vertical tratteggio. Finally, the larger lacunae, connected to specific historical and conservative vicissitudes such as hammering and perimeter deficiencies (evidence of the transformation of the artwork into a fragment) were treated with an under level light-colored mortar (Mulazzani et al. 1977).

The conservative history of Bramante's paintings was therefore very complex and a correct understanding of their state of conservation and their current image must consider this history which has profoundly marked the subject and the fruition of the works.
The last treatment (2016-2018) had the double purpose of solving the conservative problems, albeit not particularly serious (only briefly mentioned here for reasons of space), and improve the fragmentary reading of the images due to the presence of numerous lacunae previously treated with a neutral color mortar. The main objective was the reestablishing of the continuity of the figurative text, essential to make Bramante's pictorial work more comprehensible.

The conservation project was also born from a specific need of the Pinacoteca di Brera to update the overall aesthetic presentation of the eight paintings: that is, to restore the integrity of the figures and to improve the understanding of their link with the painted architectural space, which was originally in close relationship with the real environment.

The conservation treatment carried out by the CCR was supported by an articulated multispectral diagnostic campaign (UV fluorescence, infrared reflectography 950 $\mathrm{nm}$, infrared false-color post-production), followed by in-depth, non-invasive (X-Ray Fluorescence, Fiber Optics Reflectance Spectroscopy) and micro-destructive scientific analyses (Fourier Transform Infrared Spectroscopy and visible light and UV fluorescence optical microscopy and SEM-EDX), aimed at understanding the conservation issues e and the execution technique. For example, the surface whitening visible in the Man with a Two-Handed Sword and in the Man with a mace was investigated through the FTIR analysis: this phenomenon is due to the alteration of a thin layer of acacia gum applied as a consolidating material during Mrs. Brambilla's treatment.

This analysis was also very useful to identify the materials used to fill the lacunae during the previous treatments. Thanks to SEM-EDX and FT-IR analysis we have found different kind of fillers: some of them are made with traditional chalk and glue and other more yellowish fillers are made up of a mixture of calcium sulphate, barium, silica and an acrylic resin, probably added to make the stucco more elastic. Aesthetic mortars below level were also sampled and analyzed using the EDX microprobe: they are made of a heterogeneous grain (200 and $50 \mu \mathrm{m})$ of: limestone, calcite, quartz, dolomite, apatite, ilmenite.

It was also possible to verify the presence of white lead residues, attributable to the old overpaintings, and of recent watercolor retouches made with chrome-based green and red, zinc- and titanium-based white, limited to the light-color backgrounds of the architectural elements.

On the back of the stretchers, there is a label with the inscription: "12-20 August 1978 pest control". This information was useful to explain the unusual bromine signal, detected with XRF, on all the paintings. This chemical element is attributable to an alkyl bromide biocide treatment (Caneva 1996), which has reached the pictorial surface by impregnating the PVA panels from the back and the cotton canvas supports. 


\section{Notes on the execution technique}

The diagnostic campaign was also aimed at the study of the original materials with particular attention to the composition of the mortars and the characterization of the pigments. The SEM-EDX analysis carried out on the Man with halberd revealed the use of a mortar with a carbonate matrix, with magnesium hydroxide and silicates. Regarding the pictorial palette of Bramante, we observe the widespread use of a calcium carbonate based white, ochre and/or yellow and red earth, umber earth, green earth. There is a limited use of: lead and tin yellow (Man with a mace), malachite (Man with halberd) and azurite in the globe of Heraclitus and Democritus, probably all dry applied with an organic binder.

The wall paintings were layered using buon fresco technique with ample dry finishes which, unfortunately, given their greater fragility, have suffered the most substantial damage. The paintings, albeit the treatments undergone, still have good material characteristics that allow the study of the execution technique. By observing the surface with raking light, it was possible, for example, to identify the "giornate" of the intonaco.

For the underdrawing, Bramante adopted the traditional techniques reported in the reference treatises by alternating the use of engravings, spolvero and drawing with a brush (Cornale et al. 2005, Rinaldi 2011). Indirect engravings have been used to define: the outline of the architectural elements, the geometric shapes and some details of the garments. These engraved lines, of variable depth and width, indicate in a synthetic way the profiles of the elements brought subsequently to completion without the use of the preparatory drawing. In the pilasters that mark the semicircular space of the niches present in all the backgrounds, we find the socalled "battitura dei fili" technique used to precisely trace the vertical lines of architectural elements. Also, in the pilasters, the decorative motifs of the capitals show the unmistakable signs left by spolvero: small black dots outline the border of the ornamental motifs and suggest the existence of a cardboard used as a model to reproduce the decoration.

In those areas where the pictorial film decayed, the preparatory drawing made to describe the figures emerges. The painting Man with Halberd is quite interesting in this respect: on the right side of the hair, we can observe some very fluid brown lines realized with a brush to quickly set the bulk of the hair itself. In this case, these are very synthetic pure contour lines that outline the shapes of the figures without describing the details or the chiaroscuro. Furthermore, through the observation of the pictorial layers, it was possible to notice the great fluidity of the brushstrokes and the small strokes of light made with more substantial and material lime strokes.

\section{State of conservation}

Considering the complex history of the pictorial cycle, with particular reference to the detaching treatment of
1901, the paintings, overall, presented a mediocre state of conservation.

On the paintings, in addition to the widespread deposits of dust whose accumulation was favored by the irregularity of the pictorial surface, a localized phenomenon of deadhesion was found between the support canvas (applied during the 1901 treatment) and the added polyvinyl panel placed during Mrs. Brambilla's treatment. These detachments, easily visible in raking light, appear as deformations with an irregular shape capable of compromising the flatness of the works.

In the paintings that still show the entire figures, an evident superficial whitening was also visible due to the micro-fragmentation of a protective product of natural origin (Arabic gum) applied during previous treatments in order to revive the color backgrounds. The combination of the degradation of this protective layer and the presence of residues of a substance of brown color, identified as glue of protein nature and associated with the detachment treatment, negatively influenced the correct reading of the figures and the colors.

The close inspection of the works and the vision by Wood's lamp also made it possible to pinpoint the numerous pictorial integrations carried out directly on the original mortars or on gesso and glue fillings. In both cases these retouches were characterized by a strong chromatic alteration: a yellowish shade caused by the progressive discoloration of the materials used for retouching (watercolors) and the intense yellowing from the stucco used to fill the lacunae. In this regard, the response to the UV fluorescence of the material used for filling lacunae (then retouched with watercolors) during Mrs. Brambilla's treatment, characterized by an intense yellow color.

\section{CCR conservation treatment (2016-2018)}

The first phases of the treatment involved the consolidation of the detached parts of pictorial film, the re-adhesion and the smoothing of the areas that presented detachments between the panels and the support canvas. This was achieved by infiltration with syringes of single-component adhesive based on acrylic polymers and fluoride-elastomers (Fluoline A), followed by controlled and gradual pressure up to evaporation of the volatile component.

The cleaning of the pictorial surfaces from the incoherent deposits and the subsequent removal of substances due to previous treatment have been tackled in a progressive and selective way, evaluating the most suitable methodology and materials based on specific tests. In fact, the surfaces at the end of each treatment were observed with a video microscope and a stereomicroscope to evaluate, in the most objective way, the level of cleaning achieved and the possible residues. 
Dry cleaning with high density and latex free polyurethane sponges (Daffner \& Johann) was followed by surface cleaning with a neutral buffer solution (1M of sodium hydroxide and phosphoric acid), respecting the $\mathrm{pH}$ medium value of 7,5 detected thanks to a gelled agarose disc inserted between the pictorial surface and the electrodes of the contact conductivity controller (Cremonesi 2019).

This solution allowed to remove the whitening phenomena with localized demineralized water packs supported by Japanese Bollorè paper (weight $22 \mathrm{~g} / \mathrm{m}^{2}$ ). The Japanese paper remained on the surface until completely dry: this also allowed the complete removal of coherent deposits from the surface.

While on the one hand the cleaning treatment made it possible to recover an unprecedented brightness and intensity of the original colors, on the other it made the chromatic alteration of the previous touch-ups even more evident. Because of this reason, they were removed. During this operation, the previous fillings overflowing onto Bramante's original materials, were also removed.

The fillings made with neutral mortar were removed with a scalpel or a micro scaler equipped with an abrasive tip only when they hindered the application of the new stucco, while the plaster and glue fillings were softened with water and removed with scalpel.

The most significant recovery in this sense concerns Man with halberd: under the right eye, in fact, the removal of the stucco has led to the recovery of a precious fragment of original paint useful to reconstruct the correct course of the nose.

\section{Retouching: reflections and proposed solutions}

The retouching treatment was from the beginning the most complex and delicate of the technical phases to be faced during the restoration. The first consideration was to attempt a new aesthetic presentation of Bramante's cycle proposing a solution that, while enhancing the exceptional pictorial quality of the works, allowed to maintain a fundamental aspect: their nature as fragmentary wall paintings.

For this reason, according to the criteria that guided Mrs. Brambilla's treatment, the lacunae on the perimeter have been preserved, maintaining with them also the previous under-level fillings with a neutral-colored mortar, still in excellent condition. This made it possible to preserve the fragmented identity of the works, now out-of-context, without incurring into the risk of depriving them of their history and turning them into "easel paintings".

Vice versa, during the recent treatment, the lack of paint and intonaco located inside the paintings, in the past also filled with neutral color, were treated differently.

The criteria that guided the treatment of hammering areas are the result of careful and in-depth assessments shared with the Pinacoteca di Brera: the approach was gradual and subject to continuous assessments, making every decision within a more articulated reasoning that takes into account the need to preserve the evidence of historical and conservative events and to restore, where possible, the visual integrity of the works, from the material and aesthetic point of view. For this purpose, it was necessary first of all to restore the unity between two fundamental aspects of these artworks: the painted architectural space and the figures.

In this working perspective, considering the pictorial cycle as a whole, an integration methodology was developed, able to adapt to the specific problems of each individual work, to guarantee a uniform result. For this reason the retouching has been developed during the work in two distinct phases: initially, only the lacunae by accidental damage were treated; only later those with the lack of color, such as hammering areas, due to voluntary actions that characterized the history of the artworks [Figure 3].

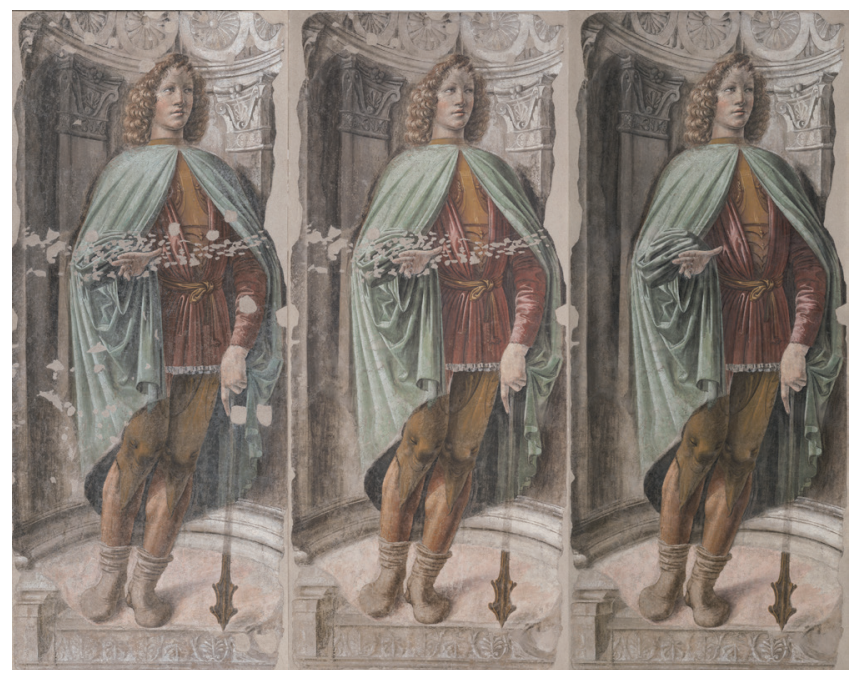

Figure 3.- Man with the Mace: before, during and after the CCR conservation treatment.

The stucco fillings were carried out on level by applying with a spatula a lightened paste filler made of acrylic resin and hollow silica microspheres (Stuccoforte light by Max Meyer), chosen for the elasticity of the material, the possibility of apply very thin layers, for its low specific weight, for the absence of water and shrinkage during the drying phase, for its excellent properties during aging tests, ease at removal and retractability of surfaces (Giovannone 2015). Carrara Marble dust and fine-grained siliceous sand (respectively $80 \%$ and $20 \%$ ) were added to this material (in a 1:1 ratio) in order to obtain a mixture with a particle size similar to the original limewash, but with a lighter color in order to make the integration of the lacunae in white-tinted areas easier. 
Based on the suggestions of the Works Management of Brera, inclined to the pictorial integration of the lacunae within the paintings, a proposal was elaborated which, while maintaining the reconstructed areas recognizable, allowed to restore the chromatic and figurative unity and to improve significantly the legibility of the artworks. It was possible to make this proposal because the lacunae, although very numerous, were small and involved areas of the artworks that could be easily reconstructed without the risk of subjective or arbitrary interpretations. Specifically, the lacunae essentially affected the architectures painted in the background and the garments made with flat colors substantially devoid of chiaroscuro [Figure 4]. Once the possibility of restore the image and the shape was verified, we decided to adopt the tratteggio (hatching) retouching technique which guaranteed the criteria of recognizability and reversibility and made it possible to re-establish the material value of the image.

The entire retouching phase was carried out exclusively with Winsor \& Newton extra-fine in tube watercolors, without the use of white replaced by the light color of the new fillings. Despite the artworks are exhibited in a climatically controlled museum, it was considered appropriate to reduce the retouching color palette, trying to use mostly those reported in recent studies (Pelosi 2009; Di Marcello 2011) for their greater resistance to aging: Indian red, raw umber, burnt umber, yellow ocher, chrome green, ultramarine blue and ivory black.

The retouching methodology was developed by using two different techniques depending on the different types of lacunae to be treated. On the recently completed fillings, we opted for a "broken" vertical tratteggio with pure colors that allowed us to reconstruct the missing portions, guaranteeing the principle of recognizing the treatment [Figure 5]. On the other hand, the abrasions of pictorial film were treated with small mimetic under-glazes in order to harmonize again the color areas.

At the end of the retouching phase, the images have regained a new and unprecedented readability. The not

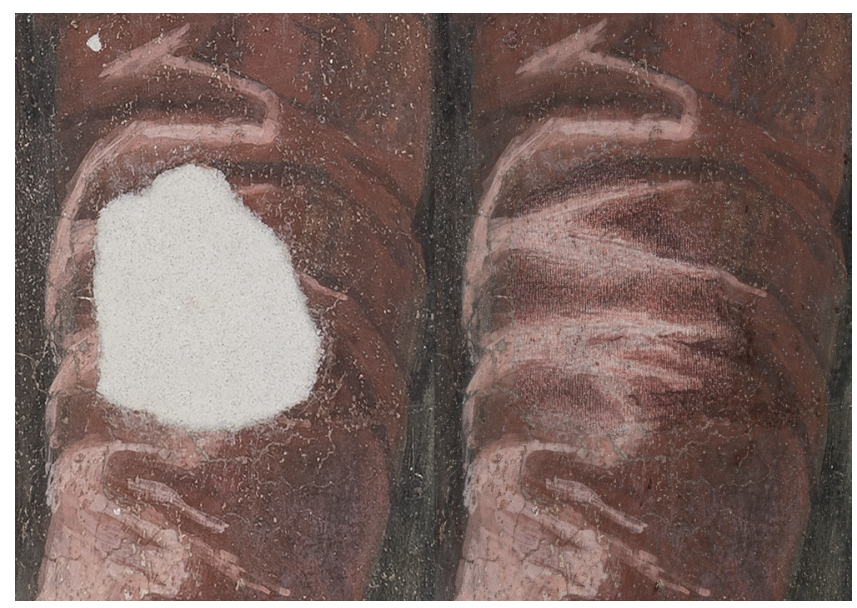

Figure 5.- Man with the Mace: detail of a lacuna before and after the retouching

easy choice to renounce, perceptively, on hammering on the backgrounds, for example, has allowed to recover Bramante's typical architectural space. Similarly, the reintegration of the numerous hammerings on the right hand of the Man with the Mace allowed a better understanding of the shape and the perspective of the arm.

In the paintings Heraclitus and Democritus and Man with a Halberd there were several areas with lacunae of only the pictorial film and intonaco on sight. In these cases, the stucco filling on the original finishing plaster was obviously not carried out, but the individual areas of color were reconnected with a semitransparent glaze. In the Man with a Halberd, moreover, following the removal of the previous retouches changed in tone, more extensive abrasions emerged, mainly in correspondence of the left eye. In this case, in continuity with the choices adopted during the previous treatment, it was decided to treat the areas with missing pictorial film with a mimetic retouching: this in order not to alter a fundamental portion of the figure and not to compromise the perception of an image that has already settled in the collective memory [Figure 6].

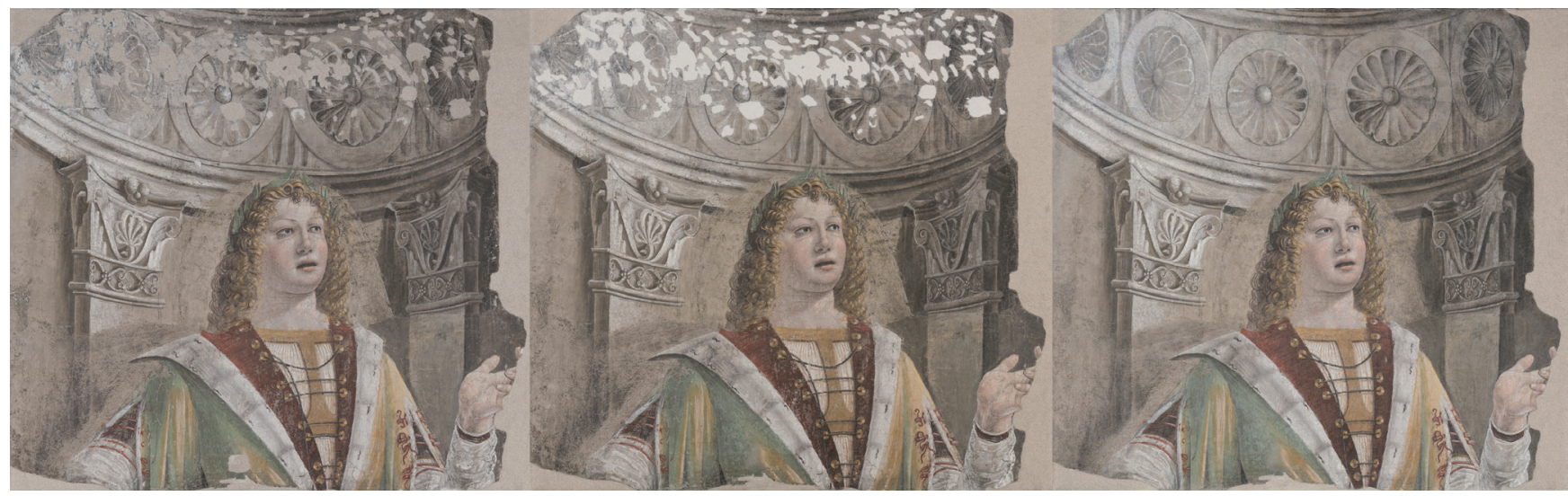

Figure 4.- The Chantor: before, during and after the CCR retouching treatment. 


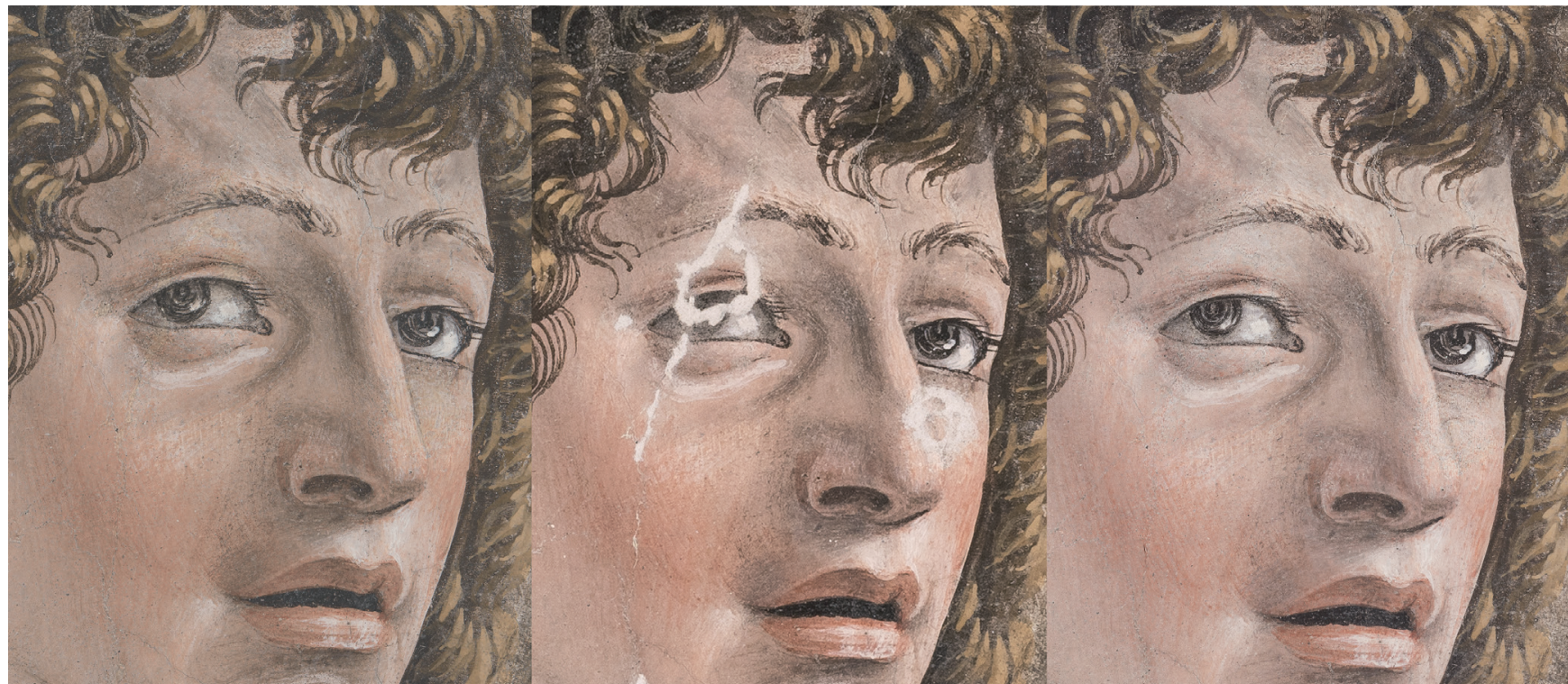

Figure 6.- Man with Halberd: detail of the face before, during and after the CCR conservation treatment.

\section{Conclusions}

The archival research and the study of the conservative history of the Men at arms by Donato Bramante provided a solid starting point for the recent restoration. This study, in fact, allowed to acquire a new awareness about the evolution over time of the topic of retouching and the criteria that guided the interpretation of these paintings in the last two centuries.

The restoration described in this paper provided a new and updated aesthetic presentation of the artworks, respecting their material characteristics and, compatibly with the conservative needs, their complex history. According to the will of the owner, the treatment reestablished the unity of the figurative text, previously fragmented by the numerous gaps left visible during previous restorations.
The retouching treatment, following the tradition of Cesare Brandi, restored a balance between the figures and the architectural space in which they are depicted. It is also important to underline that this is the result of a strong methodology, capable of considering at the same time the specificity of each artwork without ever losing the overall vision of the pictorial cycle: it is a proposal that absolutely does not want to be considered definitive but remains open to future reflections and revisions [Figure 7].

*Work group - Conservation Laboratories: Michela Cardinali (Director), Marie-Claire Canepa, Alessandro Gatti with Alessandra Bassi, Sara Callegari, Gianna Ferraris di Celle, Soledad Mamani, Valentina Parlato, Davide Puglisi; Scientific Laboratories: Daniele Demonte, Paolo Triolo; Tiziana Cavaleri, Marco Nervo, Chiara Ricci; Art historian: Marianna Ferrero.

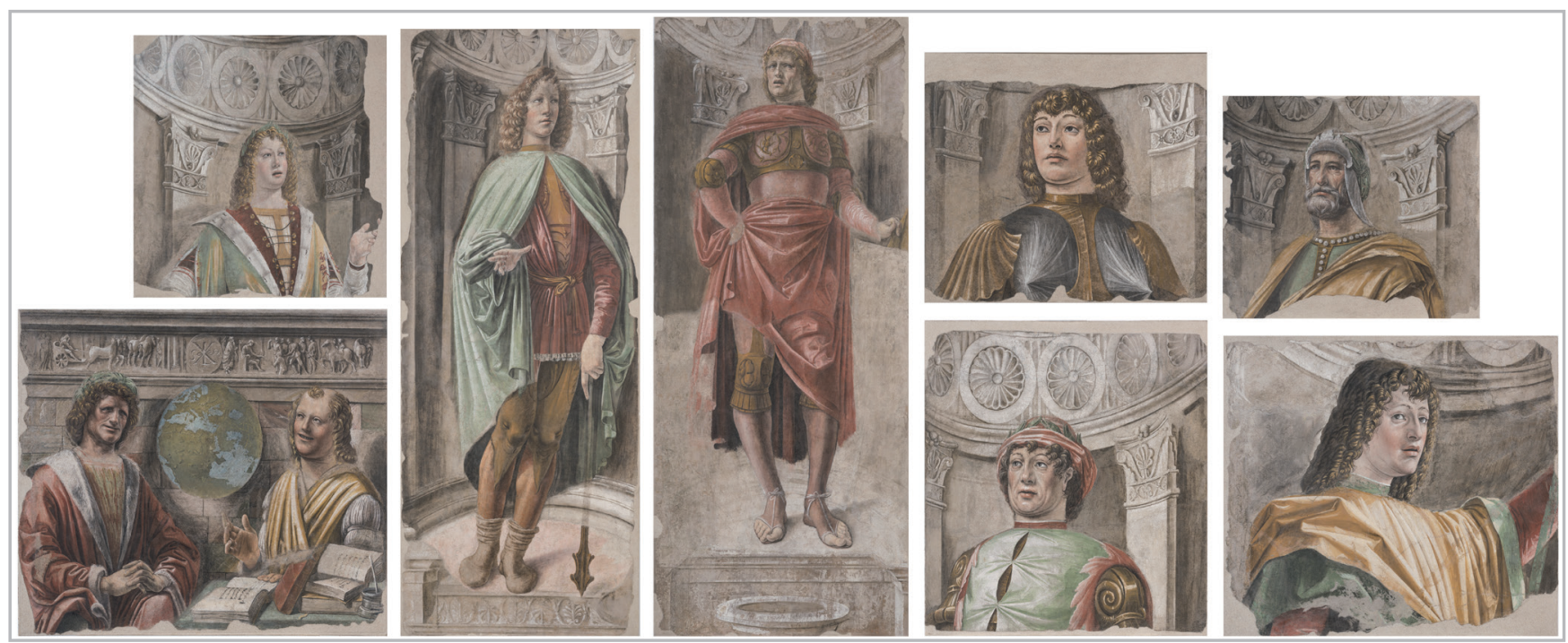

Figure 7.- "Men at arms": the paintings after the conservation treatment. 


\section{References}

AUTELLI F. (1989). Pitture murali a Brera. Bergamo: Istituto per la storia dell'arte lombarda.

BASILE G. (2010). "La restituzione del testo pittorico nel ciclo di Giotto alla cappella Scrovegni e nei dipinti murali della Basilica Superiore di San Francesco in Assisi". In: I colori di Giotto. La Basilica di Assisi: restauro e restituzione virtuale. http://www.giuseppebasile. org/restauri/la-basilica-di-s-francesco-ad-assisi/37-la-restituzionedel-testo-pittorico-nel-ciclo-di-giotto-alla-cappella-scrovegni-enei-dipinti-murali-della-basilica-superiore-di-san-francesco-inassisi, [accessed 13/04/2020].

BASILE G. (2014). "I ritocchi e le integrazioni”. In: PHILIPPOT P. Istituto Centrale del Restauro, la sua organizzazione ele sue posizioni riguardo ai principali problemi del restauro dei dipinti . Palermo: Provenzani Editore. 176-185.

CASAZZA O. (2007). Il restauro pittorico nell'unità di metodologia. Florence: Nardini.

CORNALE P., MARITAN L., MAZZOLI C. et al. (2005). "Affresco e mezzo fresco: studio sperimentale e procedure analitiche per la caratterizzazione delle tecniche pittoriche". In: Sulle pitture murali: Riflessioni. Conoscenze. Interventi, Proceedings of the Conference Scienza e beni culturali XXI. Marghera: Arcadia Ricerche. 687-696.

CREMONESI P. (2019). L'ambiente acquoso per il trattamento di manufatti artistici. Padova: II Prato.

DI MARCELLO S., NOTARSTEFANO C. (2011). "La verifica della durabilità dei colori ad acquerello impiegati nella reintegrazione dei dipinti murali". In A scuola di restauro: le tesi migliori degli allievi dell'Istituto Superiore per la Conservazione ed il Restauro e dell'Opificio delle Pietre Dure negli anni 2005-2007. Rome: Gangemi. 71-81.

GIANNINI C. (2006). Giovanni Secco Suardo alle origini del restauro moderno. Florence: Edifir.

GIANNINI C. (2013). "Attilio Steffanoni (1881-1947). Biografia di un collezionista restauratore". In: La cultura del restauro. Modelli di ricezione per la museologia e la storia dell'arte. Proceedings of the Conference. Rome: Campisano Editore. 595-606.

GIOVANNONE C., OZINO E., SCARPITTI P. et. al. (2015). “Uno stucco particolare per i dipinti murali staccati di Giusto dei Menabuoi del battistero di della cattedrale di Padova". In: Proceedings of the Conference Lo Stato dell'Arte XIII. Florence. 89-101.

GRAZIOSI F. (2011).“Le alterazioni dei materiali per la reintegrazione pittorica dei dipinti murali". In A scuola di restauro: le tesi migliori degli allievi dell'Istituto Superiore per la Conservazione ed il Restauro e dell'Opificio delle Pietre Dure negli anni 2005-2007. Rome: Gangemi. 93-100.

MARIOTTI P.I. (2014). “L'Annunciazione di Sandro Botticelli proveniente dallo Spedale di San Martino alla Scala: dal distacco di Lucarini alle problematiche attuali", OPD Restauro, 26: 151-164.
MULAZZANI G., DALAI EMILIANI M., MATALON S., et. al. (1977). Donato Bramante: gli Uomini d'arme. Florence: Centro Di.

NADOLNY J. (2012). "History of visual compensation for paintings". In: The Conservation of Easel Paintings. New York: Routledge. 573585.

PELOSI C., MARABELLI M., FALCUCCI C. et. al. (2009). "Problematiche conservative degli acquerelli nel restauro". Archeomatica, 0: 24-27.

RINALDI S. (2011). Storia tecnica dell'arte. Materiali e metodi della pittura e della scultura (secc. V-XIX). Rome: Carocci.

ROSSI F. (2014). "A margine di Luca Beltrami disegnatore e dei suoi doni". In: Luca Beltrami (1854-1933). Storia, arte e architettura a Milano. Milan: Silvana Editoriale. 239-249.

SÁNCHEZ ORTIZ A., SÁNCHEZ LEDESMA A., SEDANO ESPÍN U. et. al. (2009). "Investigación sobre la estabilidad química y óptica de materiales contemporáneos para reintegración cromática". En IV Congreso del GEIIC (Cáceres, 25-27 noviembre 2009), 195-205.

VV. AA (1988). Bramante a Milano. Proceedings of the Conference. Special issue of Arte Lombarda. 86-87. Milan: II Vaglio Cultura Arte.

VV. AA. (2009). Lacuna: riflessioni sulle esperienze dell'Opificio delle Pietre Dure. Proceedings of the Conference: Salone dell'arte del Restauro e della Conservazione dei Beni Culturali e Ambientali di Ferrara (7th April 2002 and 5th April 2003), Florence: Edifir.

VV. AA. (2015). Donato Bramante a Milano. Le arti in Lombardia 1477-1499. Milan: Skira.

\section{Archival references}

Milan, Historical Archive of Pinacoteca di Brera

Milan, Municipal Photographic Archive

Venaria Reale, Pinin Brambilla Barcilon Archive

\section{Author/s}

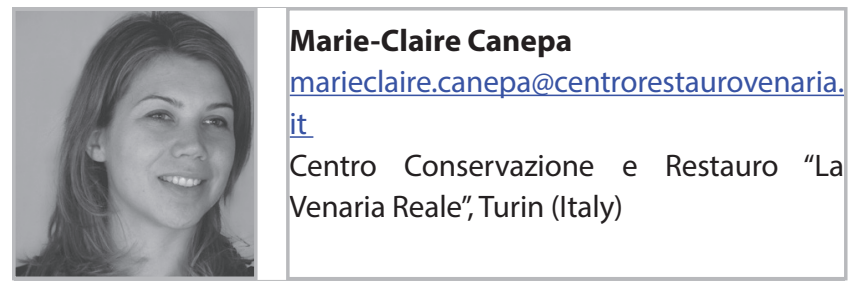

Graduated in 1998, she is a conservator specialized in mural paintings and stones, paintings on canvas and panel. Since 2006 she works in the Conservation and Restoration Center "La Venaria Reale" and since 2010 she is the Head of the conservation laboratory of stones, mural paintings, stuccoes and decorated architectural surfaces. She also works as a Teacher for the Master's Degree Program in Conservation and Restoration of Cultural Heritage (University of Turin). 

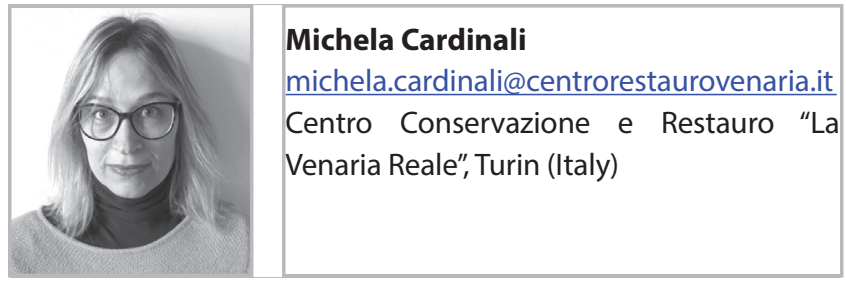

Graduated and specialized as conservator of painted surfaces on several supports and on lithic materials (Istituto Superiore Centrale per il Restauro, Rome); she got the Degree in Conservation of Cultural Heritage at the University of Tuscia. Since 2006 she works in the Conservation and Restoration Center "La Venaria Reale" (CCR): first as a conservator specialized in the field of natural stone artefacts, mural paintings and paintings on canvas and panel and as a teacher in the Master's Degree Program in Conservation and Restoration of Cultural Heritage (University of Turin); in 2012 she become Director of the Conservation Laboratories and since 2013 she is Head of the Center's Advanced Training School.
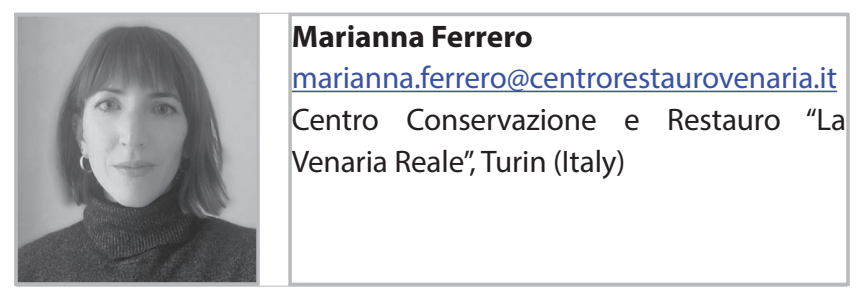

$\mathrm{He}$ is an art historian and she works in the project management department of the Conservation and Restoration Center "La Venaria Reale". In particular, she deals with conservation projects and activities of the Paintings on canvas and panel Conservation Laboratory. She graduated in Art History at the University of Turin and she got a postdegree specialization at the University of Genoa.
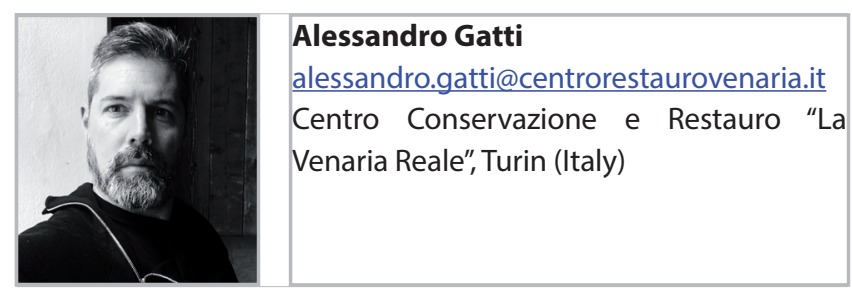

$\mathrm{He}$ is a paintings conservator with a Degree in Conservation of Cultural Heritage (University of Milan). Since 2006, he works in the Conservation and Restoration Center "La Venaria Reale": he is specialized in Venetian, Lombard and Piedmontese Renaissance paintings. He also works as a Teacher of execution techniques and conservation of canvas paintings for the Master's Degree Program in Conservation and Restoration of Cultural Heritage (University of Turin).

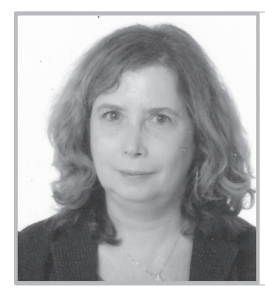

\section{Cristina Quattrini}

cristina.quattrini@beniculturali.it

Pinacoteca di Brera, Milan (Italy),

Graduated and post-graduated at the University of Milan, she got a PhD in Art History at the University of Turin and a post doc at the
University of Padua. Currently she is the curator of the Lombard and Piedmontese Renaissance paintings department at the Pinacoteca di Brera and she also deals with the Umbria, Tuscany and Marche Paintings department. She was among the curators of the Bramante's exhibition in Milan (2014). 